\title{
4
}

\section{The Volta Delta, Ghana: Challenges in an African Setting}

Samuel Nii Ardey Codjoe, Kwasi Appeaning Addo, Cynthia Addoquaye Tagoe, Benjamin Kofi Nyarko, Francisca Martey, Winfred A. Nelson, Philip-Neri Jayson-

Quashigah, D. Yaw Atiglo, Prince Osei-Wusu Adjei, Kirk Anderson, Adelina Mensah, Patrick K. Ofori-Danson, Barnabas Akurigo Amisigo, Jennifer Ayamga, Emmanuel Ekow Asmah, Joseph Kwadwo Asenso, Gertrude Owusu, Ruth Maku Quaye and Mumuni Abu

\subsection{The Volta Delta: Evolution and Biophysical Characteristics}

Located in south-eastern Ghana between Longitudes $0^{\circ} 40^{\prime} \mathrm{E}$ and $1^{\circ} 10^{\prime} \mathrm{E}$ and Latitudes $5^{\circ} 25^{\prime} \mathrm{N}$ and $6^{\circ} 20^{\prime} \mathrm{N}$, the Volta Delta of Ghana covers an area of about $4562 \mathrm{~km}^{2}$ (Appeaning Addo et al. 2018)

S. N. A. Codjoe ( $₫) \cdot$ D. Y. Atiglo · K. Anderson · G. Owusu •

R. M. Quaye · M. Abu

Regional Institute for Population Studies, University of Ghana,

Legon-Accra, Ghana

e-mail: scodjoe@ug.edu.gh

K. Appeaning Addo · P.-N. Jayson-Quashigah · P. K. Ofori-Danson

Department of Marine and Fisheries Sciences, Institute for Environment and Sanitation Studies, University of Ghana, Legon-Accra, Ghana 
(Fig. 4.1). The Volta Delta lies within the Keta Basin, which is one of several fault-controlled sedimentary basins in West Africa (Appeaning Addo et al. 2018). The basin is underlain by acid and basic gneisses and schists of the Dahomeyan system with outcrop on the northern fringes of the basin. The soil underlying the Keta Basin is soft, highly compressible organic or inorganic clays overlaying fine sand to great depth (Kumapley 1989).

The delta plain is almost flat, featureless and descends gradually from inland to the Gulf of Guinea. Several thousand years ago, the river mouth of the delta was located further east but migrated westward (Nairn et al. 1999). The repositioning of the river mouth, decrease in sediment supply and reworking of the Holocene delta plain have resulted in realignment of the delta front east of the present river mouth (Anthony 2015).

The Volta Delta falls within the south-eastern coastal plains climatic zone. Climatic conditions are influenced by two air masses, the dry north-east trade winds and the moist southwest monsoon winds, which

K. Appeaning Addo $\cdot$ A. Mensah · J. Ayamga

Institute for Environment and Sanitation Studies, University of Ghana,

Legon-Accra, Ghana

C. Addoquaye Tagoe

Institute of Statistical, Social and Economic Research,

University of Ghana, Legon-Accra, Ghana

B. K. Nyarko

Geography and Regional Planning, University of Cape Coast,

Cape Coast, Ghana

F. Martey

Research Department, Ghana Meteorological Agency,

Legon-Accra, Ghana

W. A. Nelson

National Development Planning Commission, Accra, Ghana

P. O.-W. Adjei

Department of Geography and Rural Development,

Kwame Nkrumah University of Science and Technology, Kumasi, Ghana 


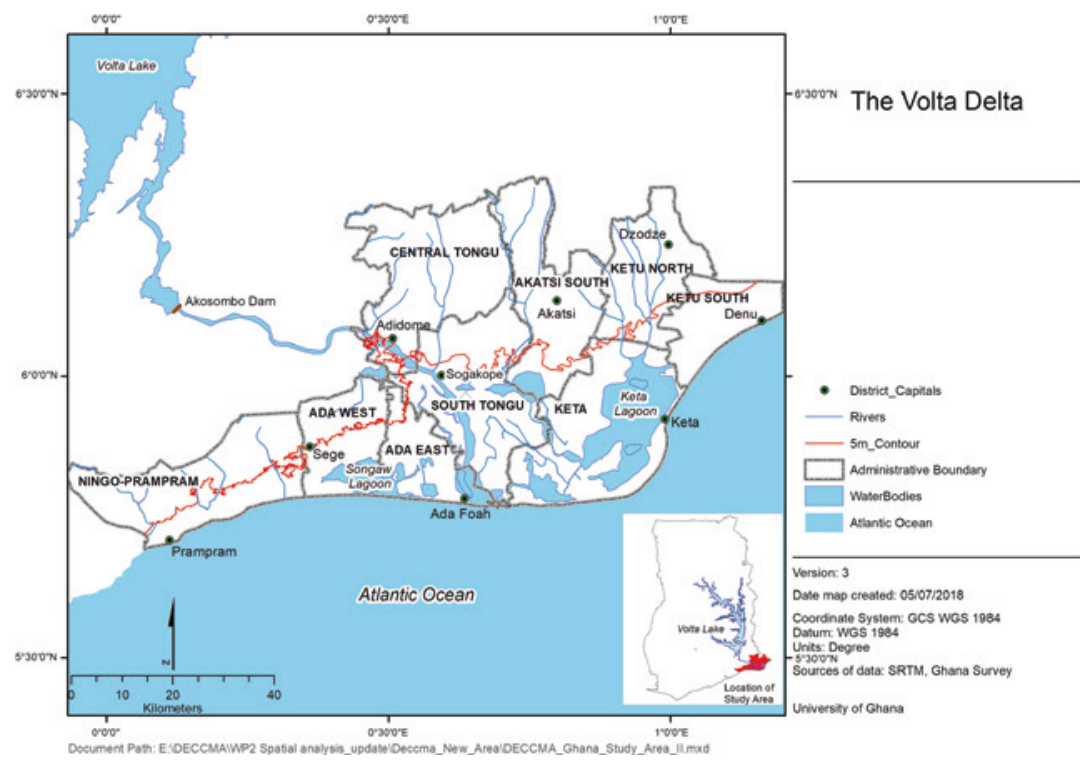

Fig. 4.1 Map of the Volta Delta area depicting the $5 \mathrm{~m}$ contour boundary of the delta and the nine administrative districts partly or wholly within the delta

produce a double maximum rainfall pattern (Gampson et al. 2017). The major rainy season falls between March and July, and the minor rainy season is between August and November. Mean annual rainfall varies between 146 and $750 \mathrm{~mm}$ between years and increases from south of the delta to its north. The dry season occurs from November to February

B. A. Amisigo

Water Research Institute, Council for Scientific

and Industrial Research, Accra, Ghana

E. Ekow Asmah

Department of Economics,

University of Cape Coast, Cape Coast, Ghana

J. K. Asenso

Ministry of Finance, Government of Ghana, Accra, Ghana 
and it is characterised by the north-east trade winds (harmattan). The mean temperature does not fall below $25^{\circ} \mathrm{C}$ (Awadzi et al. 2008).

Ocean wave action significantly shapes the delta front. Swell waves of moderate to high energy with an average height of about 1.4 metres $(\mathrm{m})$ and a long period of about 11 seconds (s) approach the shoreline unimpeded from the south to south west (Almar et al. 2015). The consistent wave action generates significant longshore currents which transport sediment eastwards, causing one of the highest rates of annual unidirectional longshore sand drift in the world (1-1.5 × $\left.106 \mathrm{~m}^{3} / \mathrm{yr}\right)$ (Nairn et al. 1999). Tides are semi-diurnal with a tidal range of about $1 \mathrm{~m}$ and generate weak currents which have limited effect on the shoreline morphology (Appeaning Addo et al. 2008).

The Volta River is one of the main sources of sediment supply to the Gulf of Guinea but its activities have been interfered with by anthropogenic activities. The river's discharge varied between 1000 $\mathrm{m}^{3} / \mathrm{s}$ in the dry season and over $6000 \mathrm{~m}^{3} / \mathrm{s}$ in the wet season before the Akosombo Dam was completed in 1965 (Anthony et al. 2015). Runoff before dam construction was $87.5 \mathrm{~mm} / \mathrm{yr}$ and more varied than the post-dam period at $73.5 \mathrm{~mm} / \mathrm{yr}$ (Oguntunde et al. 2006). The natural flooding patterns of the area have changed due to the controlled flow of water. In addition, annual sediment transport has drastically reduced by dam construction to only a fraction of the original transport with no peaks in flow discharge (Bollen et al. 2011) (see Chapter 5). The delta comprises extensive swamps, interspersed with short grassland mangrove areas, mainly red mangrove, and savannah woodland (Manson et al. 2013).

\subsection{Demographic and Socio-Economic Characteristics}

Table 4.1 presents a comparison of some key demographic characteristics of the Volta Delta and Ghana. The population of the Volta Delta as defined in Fig. 4.1 was about 850,000 in 2010 constituting about 4\% of the total population of Ghana ( 24.6 million). The population structure has a broad base with people below 15 years constituting about 
Table 4.1 Key demographic characteristics of the Volta Delta and Ghana (Data from the 2010 Ghana National Population and Housing Census [GSS 2013])

\begin{tabular}{lll}
\hline Population dynamic & Volta Delta & Ghana \\
\hline Population & 856,050 & $24,658,823$ \\
Proportion of population below 15 years & $38.0 \%$ & $38.3 \%$ \\
Proportion of population aged 65 years and above & $7.1 \%$ & $4.7 \%$ \\
Dependency ratio & 81 & 76 \\
Sex ratio & 87.0 & 95.2 \\
Proportion of female-headed households & $41 \%$ & $34 \%$ \\
Population density (persons per $\mathrm{km}^{2}$ ) & 151 & 103 \\
Total fertility rate & 3.6 & 4.0 \\
Population growth rate & $1.6 \%$ & $2.1 \%$ \\
Proportion urban & $33 \%$ & $52 \%$ \\
\hline
\end{tabular}

a third of the total population of the delta (38\%) similar to Ghana nationally $(38.3 \%)$. Further, the population aged 65 years and above constitutes $7 \%$ of the delta population which is much higher than the national level of just under 5\%. As such, the dependency ratio (84 dependent-age population per 100 population of working-age [15-64]) in the Volta Delta is higher than the national ratio (76 per 100). While the sex ratio in the delta is lower (88 males per 100 females) compared to the national average (95.2 males per 100 females), the proportion of female-headed households is higher in the Volta Delta (45\%) compared to the national average (34\%) (Appeaning Addo et al. 2018). A lower sex ratio coupled with a higher proportion of female-headed households in the Volta Delta can be attributed to high out-migration of males (Atiglo and Codjoe 2015).

The population density of the Volta Delta is 151 persons per $\mathrm{km}^{2}$ compared to 103 persons per $\mathrm{km}^{2}$ in Ghana. Both the Total Fertility Rate (3.6) and annual population growth rate (1.6\%) are lower in the Volta Delta compared with the national averages of 4.0 and $2.1 \%$ respectively. About two-thirds of the delta population is rural, however, it is projected that more than half of the population of the Volta Delta will be living in urban areas by 2035 through migration. Increasing population growth and urbanisation have altered the land cover, topography and land use in the delta region, and vegetated land has been converted to agricultural use and settlements (Appeaning Addo 2015). 
Regarding socio-economic characteristics, the dominant types of dwelling are the compound house and separate structures, and slightly over 60\% of dwelling units are owned by households (GSS 2013). Outer wall materials of buildings are mainly concrete, and cement block. Biomass (wood, charcoal, sawdust, etc.) constitutes the main source of fuel for cooking and kerosene the main source for lighting. However, considering the rapid rural electrification that has occurred in the country over the past twenty years, it is expected that more households will be connected to the national electricity grid (Kumi 2017). This will increase the number of households that use electricity for cooking and lighting. While the main source of water for drinking and domestic use is pipe-borne, unimproved sources, including groundwater from wells and open water sources (30\%) are quite common.

The two main ethnic groups in the Volta Delta are Ewe and Ga-Dangme and both are patrilineal. The dominant religion in the Volta Delta is Christianity (72\%), followed by Traditional African Religion (22\%) and Islam (3\%). Illiteracy rate for the population aged 15 years and above is about 30\%, with higher illiteracy rates for females compared to males (GSS 2013).

The Volta Delta has a diverse economic system with different but integrated sectors, i.e., agriculture including livestock rearing and fisheries, salt and sand mining, construction, trade, transport and tourism (Codjoe et al. 2017). Agriculture-related activities are very common and important for livelihoods in the delta. The crop production sector employs a higher proportion of females than males (Barry et al. 2005). Females mainly engage in processing and selling of fish and farm produce, while males mostly engage in fishing and crop production (Ayivor and Kufogbe 2001). It is, however, largely small-scale and characterised by unsophisticated technologies or irrigation systems. Coconut, for instance, was a major cash crop in the delta in the nineteenth century. However, in the 1930s, production was affected by the Cape St Paul Wilt disease leading to the collapse of the industry (Eziashi and Omamor 2010). In the last two decades, the services sector, particularly trade, transport and small and medium scale manufacturing, has seen a major boost. In recent times, aquaculture farms have been established in the River Volta and the Keta Lagoon and this industry has 
huge potential to supplement declining marine fish stocks in the future (Amponsah et al. 2015; Lauria et al. 2018).

Other emerging economic activities include charcoal burning which involves cutting of trees (Akrasi 2005) and salt production (Barry et al. 2005). Furthermore, coastal sand mining which mainly feeds the booming construction industry in the nearby cities of Accra and Tema, despite being illegal, is a common activity (Mensah 2002; Anim et al. 2013; Wiafe et al. 2013; Jonah et al. 2015). Indeed, this practice negatively influences the sediment budget and has contributed significantly to increased erosion along the coast (Appeaning Addo 2015).

Finally, the Volta Delta has very important tourist attractions such as marine turtle breeding sites located in the estuary at Totope, Lolonya, Akplabanya and Kewuse, bird watching on the Songhor and Keta Lagoons (designated wetlands and Ramsar sites which provide sanctuary for about $80 \%$ of migratory birds that transit in Ghana), fetish shrines, sacred groves and traditional festivals. Resorts located on the Volta River provide water recreational activities and attract migrants to work in the tourism industry (Codjoe et al. 2017).

Short to medium term economic projections of the delta show that the manufacturing sector could outpace the agriculture and services sectors, partly due to impacts of environmental changes on agricultural production as well as prospects for future oil production (Adjei et al. 2016). Currently, the delta remains a net importer of goods and services as economic activities are inadequate to satisfy domestic and external demands.

\subsection{Biophysical and Socio-Economic Drivers of Change}

The Volta Delta is a dynamic and rich environment that is constantly changing in time and space (Dada et al. 2016). The delta, formed some thousands of years ago from sediments deposited along the mouth of the River Volta, and has constantly undergone changes since the early Holocene (Nairn et al. 1999). Natural and anthropogenic factors 
combine in a complex system to drive such change. In most instances, the anthropogenic factors tend to exacerbate the natural effects. It is to be noted, however, that anthropogenic interventions have not always been detrimental to the environment as laws and policies have been enacted overtime to protect the natural resources in the delta area.

Climate change-related events such as rainfall variability, marine and riverine flooding, drought, sea-level rise, storm surges and increased temperature are some natural drivers of change in the biophysical conditions of the delta system (Appeaning Addo et al. 2018). Humaninduced changes occur mainly from interruptions in the hydrology, land use and the landscape. The onset of the rainy season has changed due to climate variability. However, increased rainfall intensity in the rainy season causes frequent flooding in the Volta Delta. The floods degrade the environment, threaten lives, destroy properties, and result in displacement of households. Energetic swell waves, increasing sea-level rise and storm surge aided by relatively low topography also facilitate coastal flooding. The delta coast is dynamic with high crests underlain by soft rocks which naturally expose the coast from Prampram to Aflao to flooding, erosion and shoreline recession (Ly 1980). Erosion in the Volta Delta was first reported in 1929 but posited to have existed since the 1860s, particularly in Keta (Nairn et al. 1999).

A critical characteristic of the Anthropocene delta was the construction of the Akosombo and Kpong Dams in 1964 and 1982, respectively, which drastically reduced sediment supply to the coast. This exposed it to severe wave action and erosion resulting in accelerated shoreline retreat, reduction in fresh water and fish supply down-stream (Ly 1980; Nairn et al. 1999; Tsikata 2006) and also the introduction of water hyacinths that affect aquatic life in the Volta River (Gyau-Boakye 2001). Furthermore, it has been documented that schistosomiasis infections became a public health issue in Ghana after the construction of the Akosombo Dam in the 1960s, which created extensive areas suitable for the breeding of the schistosoma host snails (Paperna 1970). The prevalence of urinary schistosomiasis was below 10\% among communities living along the river before damming in 1964 and reached as high as 80-90\% after damming by 1971 (Lavoipierre 1973; Barry et al. 2005). 
Additionally, the construction of the Tema Harbour in 1955 caused sea wave diffraction on the land along the east coast of Ghana, causing massive erosion (Ly 1980; Tsidzi and Kumapley 2001). Erosion rates of about $4 \mathrm{~m}$ per year before the construction of the dams increased to about $8 \mathrm{~m}$ per year post-dam construction (Ly 1980). To address some impacts of erosion, the Keta and Ada Sea Defence Projects were undertaken in 2001 and 2013, respectively, by the central government. These were preceded by attempts to protect the shoreline by communities in Keta and its environs, led by their traditional leaders and the government, since 1923. These earlier defence structures from colonial times were constructed with weak local materials which could not withstand the strong sea waves (Akyeampong 2002; van der Linden et al. 2013). After Ghana's independence in 1957, the government undertook a coastal protection project in 1960 using steel sheets to protect about $1,600 \mathrm{~m}$ of the Keta Township but these also corroded rapidly (van der Linden et al. 2013).

By 1996, the rate of erosion and flooding had increased, with more than half of Keta and its surrounding towns under water (Ile et al. 2014) displacing more than 10,000 people in communities within Keta and leading to losses in the millions of dollars (Oteng-Ababio et al. 2011; Danquah et al. 2014). The central government therefore undertook a sea defence project to construct a causeway across the Keta lagoon for the coastal highway, reclaim lands lost to the sea and construct houses for resettlement of displaced people (Danquah et al. 2014). Between 2001 and 2004, six groynes were constructed within the Keta area to prevent erosion and to control flooding of buildings between the Keta Lagoon and the sea (Boateng 2009). The groynes were about $190 \mathrm{~m}$ in length and $750 \mathrm{~m}$ apart (Nairn and Dibajnia 2004). In 2011, the Government of Ghana began the construction of a $30 \mathrm{~km}$ sea defence wall at Ada to protect communities against wave action (Anim et al. 2013). The defence structures have had two effects; accretion of the up-drift side and increased erosion of the down-drift side of the shoreline (Wiafe et al. 2013; Appeaning Addo 2015).

In recent times, groundwater extraction for irrigated farming practices which has the potential for enhanced subsidence of the delta at a rate of about $1 \mathrm{~mm}$ per annum as pertains in other deltas globally 
(Kortatsi et al. 2005; Appeaning Addo et al. 2018), mangrove harvesting which may cause erosion and flooding (Anim et al. 2013), prospecting for oil and gas which is expected to increase the rate of subsidence (Setordzi and Nyavor 2015) and coastal sand mining with the potential of reducing sediment budget and thus increase erosion (Appeaning Addo 2015; Appeaning Addo et al. 2018) are being widely practiced.

\subsection{Adaptation to Climate and Non-climate Change}

Households and communities in the Volta Delta employ both autonomous and planned adaptation strategies to respond to the multiple threats of climatic and non-climatic stressors. Drought and flooding (both riverine and coastal) are the most common pressures on traditional livelihoods, in addition to land degradation, land-use changes, and increasing population demands on natural resources.

In the delta, as in most parts of the country, the prioritised sectors for adaptation are agriculture, water resources and disaster risk reduction. In the post-dam Anthropocene era, the government and nongovernmental organisations have implemented a number of projects and programmes to support communities to deal with the inundation of farmlands and settlements, loss of property, salinisation of groundwater, low agricultural productivity, coastal and riverine erosion, water shortage and increased incidence of water and sanitation-related diseases. Planned adaptation activities have mainly focused on implementing change with improved technologies, building capacity (e.g., climate change awareness and adaptation governance training programmes), providing alternative livelihoods for improving food security, minimising the impacts of flooding on communities through disaster risk reduction and rural-urban development actions, improving ecological functions and services for providing sustainable access to natural resources (such as mangrove regeneration and tree planting), and improving access to water.

Evidence from a household survey carried out in 2016 (see DECCMA 2018) shows that, at the community level, about 
three-quarters of households have undertaken one or multiple forms of autonomous adaptation strategies. The main adaptation strategies undertaken by households include modification of labour utilisation which involves the use of hired labour and/or women taking up work outside the home. Also, modifications to housing structures or moving houses entirely are common. As noted earlier, houses are usually made of weak materials and may require regular modification or complete abandonment. Financial capital investments in the form of loans, insurance and joining cooperatives are also common. Among these, insurance is the least employed strategy (not shown). Migration does not feature as a major adaptation strategy among households.

Farming and fishing related adaptation strategies constitute the least used strategies in the delta as a whole. Receiving training in new fishing or farming skills is the least common adaptation strategy in the delta. However, among farming households only, purchasing farm equipment is most common (Fig. 4.2).

The most successful adaptation options for most households are strategies that increase their resilience, reduce disaster impacts and improve

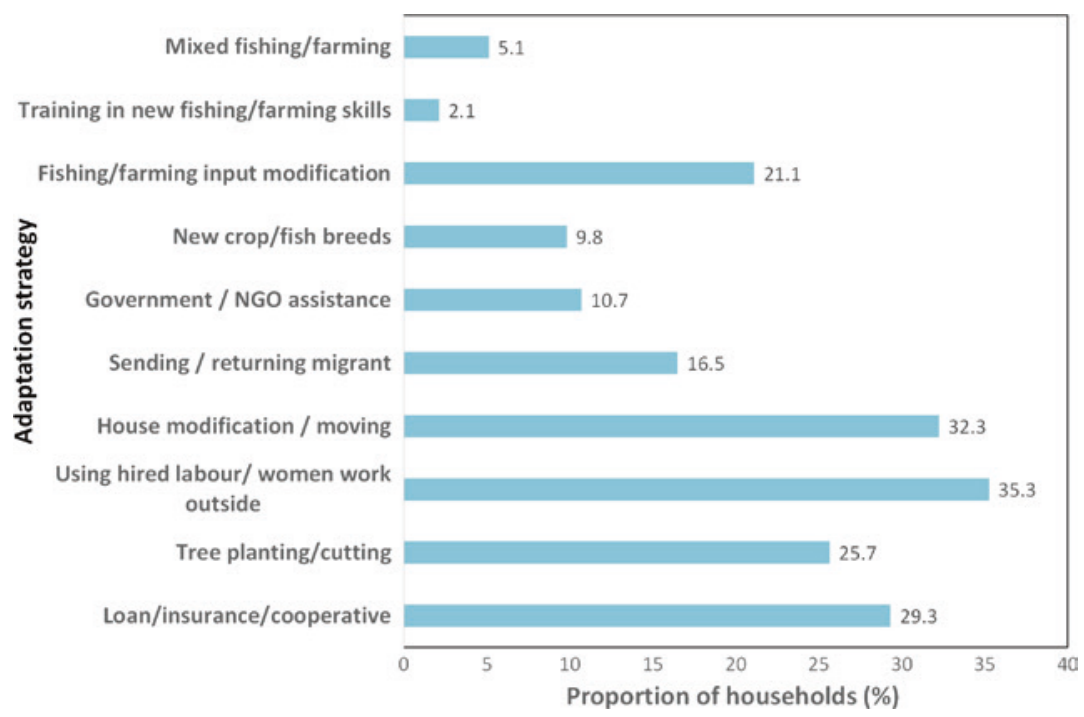

Fig. 4.2 Adaptation strategies by household adaptation strategy in the Volta Delta 
living standards by improving their overall skills and capacity for improved livelihood options. Some indications of barriers to successful adaption relate to project cost implications, the ability of targeted communities/individuals to participate or sustain participation, conflicts between original landowners and related communities over land ownership, and concerns about future loss of biodiversity and downstream pollution from the establishment of commercial agricultural farms. Other barriers include concerns over impacts of constructed sea defence structures on the movement and nesting patterns of sea turtles, the threat of non-indigenous tree species used as buffers along the banks of the Volta River becoming invasive species, and possible interruptions to water supply due to more communities getting connected to the same source.

There are positive influences on the sustainability of adaptation actions due to shared ownership and commitment by the local community through active participation in planning, design and implementation; commitment and financial support (e.g., subsidies) demonstrated by the government; self-generated funds to support action; and the use of cost effective and efficient technologies. Adaptation options that have built in sustainability and ecologically sensitive components are also more likely to be effective in the long-term for reducing disaster risk and vulnerability of the communities, and increasing resilience of the system.

Finally, gendered issues in adaptation were not prominent since both males and females generally have similar perspectives on how effective or successful an adaptation strategy is. However, introducing new breeds in fishing ponds, converting mono-cropped land to mixed farming, employing irrigation farming techniques and relocating to a new house are ranked higher by females, and males rank receiving governmental and NGO intervention and being trained with new skills higher compared to females.

\subsection{Migration and Resettlement}

The first recorded mass migration into the Volta Delta was in the sixteenth century by the Ga-Dangme and Ewe ethnic groups. Ever since this period, there has been migration to and from the delta although 
out-migration has been predominant. In the Anthropocene, the Volta Delta is a net migrant sending area, although some districts (South Tongu, Ketu South, Akatsi South, Ada East, Ada West and Prampram) are net-migrant receiving areas. Based on the results of the survey carried out for this research, the main drivers of migration from the delta are economic (employment opportunities), education and family reunion; very few individuals cite direct environmental factors as the main reason for migrating. Furthermore, higher proportions of males, mainly youth, migrate due to economic reasons, whilst more females migrate to reunite with a family or for education. It should be noted, however, that some of the economic or livelihood drivers of migration may be directly linked to climate and/or environmental change.

People who migrate for economic reasons are usually never married, cohabiting or separated. Movements from the delta area are usually permanent and there is continuous mobility from the area. Respondents in male-headed households have a higher proportion of members who intend to migrate compared to female-headed households. Although more than a third of the respondents $(42 \%)$ in the Volta Delta are of the view that migration is disruptive to individuals and the household, there is a general perception that migration is helpful. The common perception is that migration improves the socio-economic conditions of individuals and households and this feedback may continue to increase future migration from the delta, if economic opportunities are not enhanced in situ.

Some biophysical factors are associated with out-migration from the region. For example, there is already high impact of climate change on farming and fishing activities in the area. Land used for crop and vegetable cultivation and landing sites for fishers have been lost to flooding and erosion, and fresh water fishing and farming in or near the lagoon have also been affected by salinisation (Codjoe et al. 2017). In addition, the construction of the sea defence walls has not attracted people back into areas destroyed by coastal erosion or inundation due to lost livelihoods and rare economic opportunities. It is estimated that future accelerated environmental change due to the impacts of coastal erosion and flooding will lead to mass displacements and high out-migration from affected areas. 
Successive governments have considered resettling highly vulnerable communities in the delta. Prior to independence, earlier attempts to resettle communities from the Keta area failed because of the communities' attachment to their place and main livelihood activity, i.e., fishing (Akyeampong 2002). In 1996, the government undertook a comprehensive resettlement scheme for three communities in Keta-Adzido, Vodza and Kedzi (Akyeampong 2002; Afram et al. 2015). According to Afram et al. (2015), resettled communities are generally happy with the housing facilities provided but are dissatisfied with the living arrangements. In particular, people prefer to live close to their extended families and to have spaces around their homes for gatherings such as funerals and marriage ceremonies. Not incorporating these cultural and family contexts result in loss of family and cultural ties, violation of people's fundamental human rights as well as apathy for community cohesion (Danquah et al. 2014).

\subsection{Delta Management and Policy}

As shown in Table 4.2, pre-colonial management of the Volta Delta environment was primarily based on traditional/customary laws which included sanctions, taboos, cultural norms, beliefs, values, codes of conduct, etc. that were handed down over generations by oral tradition, teaching or imitation (Kuupole and Botchway 2010). Management of the delta was vested in chiefs and traditional leaders who ensured that all natural resources inherited from their predecessors were sustained for the next generation (Opoku-Agyemang 2001a). For example, there were customary rules and beliefs which prohibited fishing activities on some days and farming close to the water body or harvesting mangroves, and there were demarcated sacred groves in order to protect the serene and fragile environment (Sarpong 2004; Atampugre et al. 2016).

There is no explicit national policy devoted entirely to the Volta Delta. However, various policies contain focus areas that apply to protecting and conserving some delta features. During colonial and post-colonial times, formal rules in the form of laws, policies, protocols 


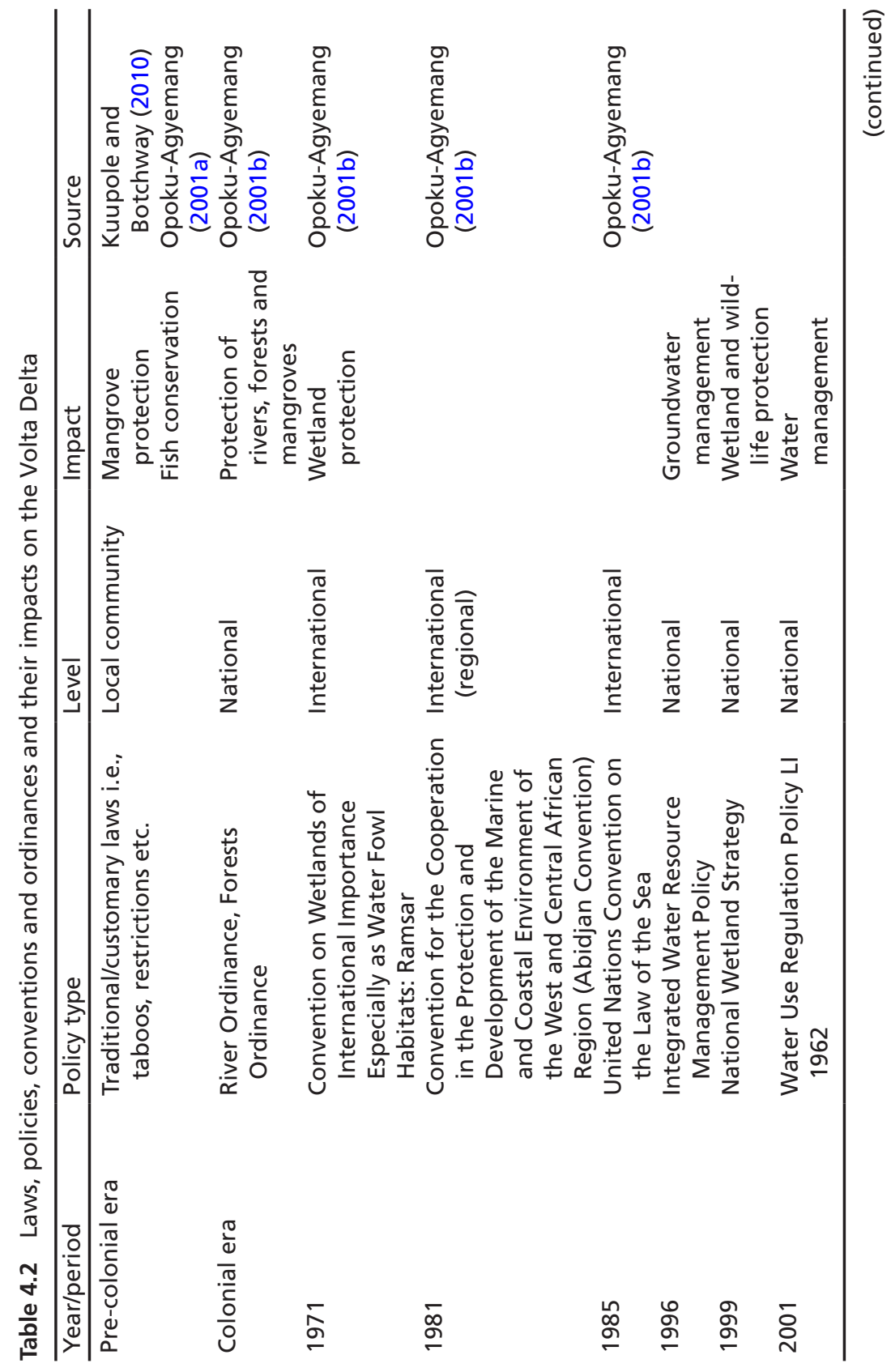




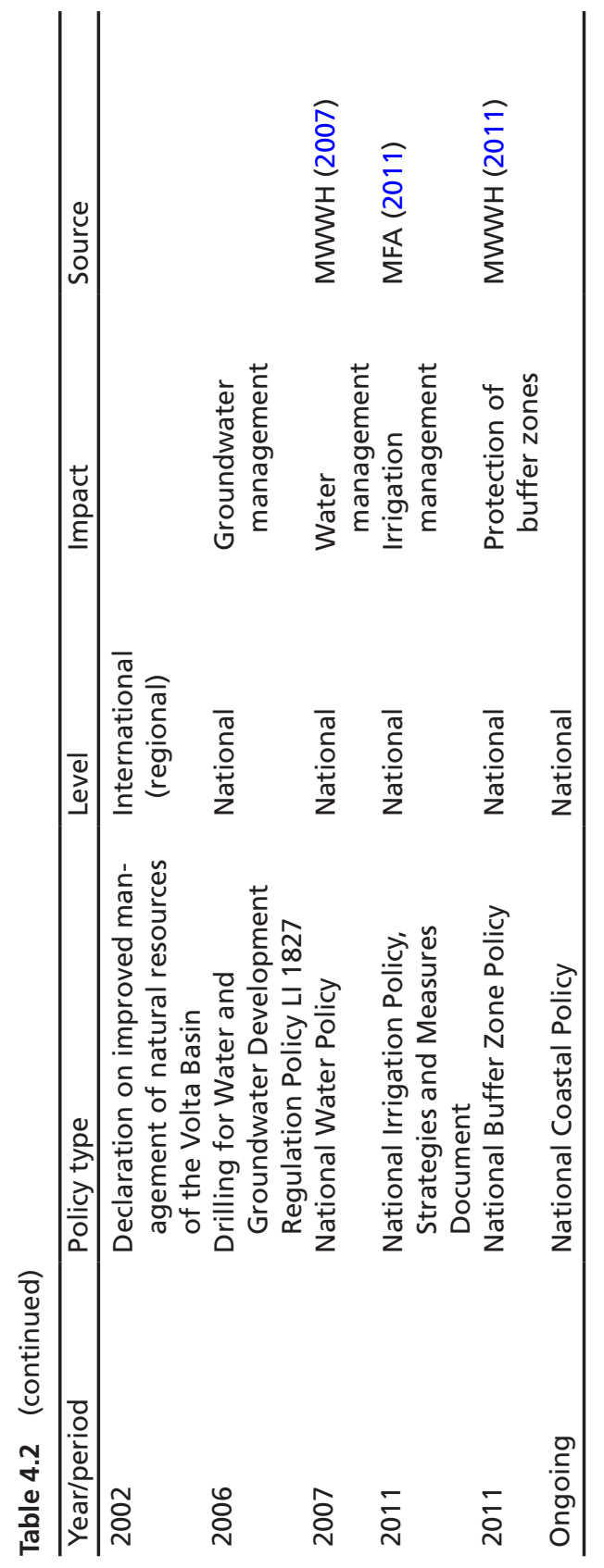


and agreements were established to ensure delta management. The earliest documented law on the Volta River Basin in Ghana was the River Ordinance of 1903 (Opoku-Agyemang 2001b) to manage the use of some rivers in the country, including the Volta, and vested powers of control over the river in the colonial governments.

National policies with focus areas that may help protect the delta include the National Water Policy; the National Wetlands Policy; the Tourism Development Policy, Land Management Policy; National Environmental Policy; Energy Policy; Minerals Policy and the Wildlife Conservation Policy. A national coastal policy is currently under development. International protocols that apply to the delta include the Convention on Wetlands of International Importance Especially as Water Fowl Habitats: Ramsar Convention (1971); International Covenant on Economic, Social and Cultural Rights (2000); United Nations Convention on the Law of the Sea (1985); Volta Basin Declaration on improved management of the natural resources of the Volta Basin (2002); Convention for the Cooperation in the Protection and Development of the Marine and Coastal Environment of the West and Central African Region (Abidjan Convention) (1981).

\subsection{Conclusion}

There has been a transitioning in the Volta Delta from the Holocene to the Anthropocene. It is evident that human activities have greatly altered the physical characteristics in the delta area and the built environment has further reshaped the nature of human settlement, livelihoods and movement. The construction of the Akosombo and Kpong Dams has had tremendous impact, not only on the geophysical characteristics of the delta, but also on the socio-economic adjustments to population livelihoods (see also Chapter 8 ). The dams have interfered with sedimentation process and repositioning of the river mouth along the Gulf of Guinea and also reduced the amount of freshwater that flows into the sea. Further, the fish population that flowed from upstream has significantly dropped. Thus, there has been outmigration from the delta area to upstream areas for freshwater fishing. 
Similarly, the construction of a fishing harbour in Tema, west of the delta has impacted the rates of erosion as well as livelihoods in the delta region. The harbour and an associated industrial city serve as an attractive hub for migrants from the delta whose main fishing-based livelihoods have been adversely impacted by the construction of the dams. Migration is dominated by males leading to a higher proportion of females in the delta.

Currently, the construction of groynes along the coasts of Keta and Ada have resulted in significant rates of accretion and reshaping of the morphology along the shoreline. The Keta sea defence project and accompanying resettlement scheme continue to have some impact on the physical nature of the delta as well as human mobility. The construction of the revetment in Atokor in the Keta Municipality has further enabled the reconstruction of the previously destroyed road and opened up the area for commercial activities. Finally, human settlements, land use and economic activities continue to reshape the land cover and biosphere of the delta area.

\section{References}

Adjei, P. O.-W., Ofori-Danson, P. K., Asenso, J. K., \& Amponsah, S. K. (2016). Biophysical and socioeconomic state of the Volta Delta region of Ghana from the perspectives of gender and spatial relations (Deltas, Vulnerability and Climate Change: Migration and Adaptation [DECCMA] Working Paper). Southampton, UK: DECCMA Consortium. https://generic.wordpress.soton. ac.uk/deccma/resources/working-papers/. Last accessed 5 December 2016. Afram, S. O., Kwofie, T. E., \& Attipoe, J. (2015, March 25-26). The influence of beneficiary participation in resettlement schemes in Ghana. A case study of the Keta Basin Sea Defence Resettlement Project. Proceedings of the 4th International Conference on infrastructure Development in Africa, Kumasi, Ghana.

Akrasi, S. A. (2005). The assessment of suspended sediment inputs to Volta Lake. Lakes \& Reservoirs: Science, Policy and Management for Sustainable Use, 10(3), 179-186. https://doi.org/10.1111/j.1440-1770.2005.00272.x. Akyeampong, E. (2002). Between the sea and the lagoon: An eco-social history of the Anlo of southeastern Ghana, c. 1850 to recent times. Martlesham, UK: James Currey. 
Almar, R., Kestenare, E., Reyns, J., Jouanno, J., Anthony, E. J., Laibi, R., et al. (2015). Response of the Bight of Benin (Gulf of Guinea, West Africa) coastline to anthropogenic and natural forcing, Part1: Wave climate variability and impacts on the longshore sediment transport. Continental Shelf Research, 110, 48-59. https://doi.org/10.1016/j.csr.2015.09.020.

Amponsah, S. K., Danson, P. O., Nunoo, F. K. E., \& Lamptey, A. M. (2015). Assessment of security of coastal fishing in Ghan a from the perspectives of safety, poverty and catches (Master's thesis). University of Ghana, Accra, Ghana.

Anim, D. O., Nkrumah, P. N., \& David, N. M. (2013). A rapid overview of coastal erosion in Ghana. International Journal of Scientific \& Engineering Research, 4(2), 1-7.

Anthony, E. J. (2015). Patterns of sand spit development and their management implications on deltaic, drift-aligned coasts: The cases of the Senegal and Volta River delta spits, West Africa. In G. Randazzo, D. Jackson, \& A. Cooper (Eds.), Sand and gravel spits (pp. 21-36). Heidelberg, Germany: Springer.

Anthony, E. J., Brunier, G., Besset, M., Goichot, M., Dussouillez, P., \& Nguyen, V. L. (2015). Linking rapid erosion of the Mekong River delta to human activities. Scientific Reports, 5. https://doi.org/10.1038/srep14745.

Appeaning Addo, K. (2015). Monitoring sea level rise-induced hazards along the coast of Accra in Ghana. Natural Hazards, 78(2), 1293-1307. https:// doi.org/10.1007/s11069-015-1771-1.

Appeaning Addo, K., Nicholls, R. J., Codjoe, S. N. A., \& Abu, M. (2018). A biophysical and socioeconomic review of the Volta Delta, Ghana. Journal of Coastal Research. https://doi.org/10.2112/JCOASTRES-D-17-00129.1.

Appeaning Addo, K., Walkden, M., \& Mills, J. P. (2008). Detection, measurement and prediction of shoreline recession in Accra, Ghana. ISPRS Journal of Photogrammetry and Remote Sensing, 63(5), 543-558. https://doi. org/10.1016/j.isprsjprs.2008.04.001.

Atampugre, G., Botchway, D.-V. N. Y. M., Esia-Donkoh, K., \& Kendie, S. (2016). Ecological modernization and water resource management: A critique of institutional transitions in Ghana. GeoJournal, 81(3), 367-378. https://doi.org/10.1007/s10708-015-9623-9.

Atiglo, D. Y., \& Codjoe, S. N. A. (2015). Migration in the volta delta: A review of relevant literature (Deltas, Vulnerability and Climate Change: Migration and Adapation [DECCMA] Working Paper). IDRC Project Number 107642. www.deccma.com.

Awadzi, T. W., Ahiabor, E., \& Breuning-Madsen, H. (2008). The soil-land use system in a sand spit area in the semi-arid coastal savanna region of Ghana: 
Development, sustainability and threats. West African Journal of Ecology, 13, 132-143. https://doi.org/10.4314/wajae.v13i1.40573.

Ayivor, J. S., \& Kufogbe, S. K. (2001). Post-dam agro-ecological challanges of the lower volta basin in Ghana. Bulletin of the Ghana Geographical Association, 23(1), 88-102.

Barry, B., Obuobie, E., Andreini, M., Andah, W., \& Pluquet, M. (2005). The Volta river basin. Comparative study of river basin development and management (Report), p. 51. Colombo, Sri Lanka: International Water Management Institute (IWMI) and Comprehensive Assessment of Water Management in Agriculture (CAWMA). http://www.iwmi.cgiar.org/assessment/files_new/research_projects/river_basin_development_and_management/VoltaRiverBasin_Boubacar.pdf. Last accessed 14 August 2018.

Boateng, I. (2009, May 3-8). Development of integrated shoreline management planning: A case study of Keta. Federation of International Surveyors Working Week. Eilat, Israel. https:/www.fig.net/resources/proceedings/fig_proceedings/ fig2009/papers/ts04e/ts04e_boateng_3463.pdf. Last accessed 14 August 2018.

Bollen, M., Trouw, K., Lerouge, F., Gruwez, V., Bolle, A., Hoffman, B., et al. (2011). Design of a coastal protection scheme for Ada at the Volta River mouth (Ghana). Proceedings of 32nd Conference on Coastal Engineering, 2010. Shanghai, China. International Conference on Coastal Engineering (ICCE). https://doi.org/10.9753/icce.v32.management.36.

Codjoe, S. N. A., Nyamedor, F. H., Sward, J., \& Dovie, D. B. (2017). Environmental hazard and migration intentions in a coastal area in Ghana: A case of sea flooding. Population and Environment, 39(2), 128-146. https://doi.org/10.1007/s11111-017-0284-0.

Dada, O. A., Li, G., Qiao, L., Ma, Y., Ding, D., Xu, J., et al. (2016). Response of waves and coastline evolution to climate variability off the Niger Delta coast during the past 110 years. Journal of Marine Systems, 160, 64-80. https://doi.org/10.1016/j.jmarsys.2016.04.005.

Danquah, J. A., Attippoe, J. A., \& Ankrah, J. S. (2014). Assessment of residential satisfaction in the resettlement towns of the Keta Basin in Ghana. International Journal of Civil Engineering, Construction and Estate Management, 2(3), 26-45.

DECCMA. (2018). Climate change, migration and adaptation in deltas: Key findings from the DECCMA project (Deltas, Vulnerability and Climate Change: Migration and Adaptation [DECCMA] Report). Southampton, UK: DECCMA Consortium. https://www.preventionweb.net/publications/ view/61576. Last accessed 27 November 2018. 
Eziashi, E., \& Omamor, I. (2010). Lethal yellowing disease of the coconut palms (cocos nucifera 1.): An overview of the crises. African Journal of Biotechnology, 9(54), 9122-9127.

Gampson, E. K., Nartey, V. K., Golow, A. A., Akiti, T. T., Sarfo, M. A., Salifu, M., et al. (2017). Physical and isotopic characteristics in peri-urban landscapes: A case study at the lower Volta River Basin. Ghana. Applied Water Science, 7(2), 729-744. https://doi.org/10.1007/s13201-015-0286-y.

GSS. (2013). 2010 population and housing census (National Analytical Report). Accra, Ghana: Ghana Statistical Service. http://www.statsghana.gov.gh/ docfiles/publications/2010_PHC_National_Analytical_Report.pdf. Last accessed 28 August 2018.

Gyau-Boakye, P. (2001). Environmental impacts of the Akosombo Dam and effects of climate change on the lake levels. Environment, Development and Sustainability, 3(1), 17-29. https://doi.org/10.1023/A:1011402116047.

Ile, I. U., Garr, E. Q., \& Ukpere, W. I. (2014). Monitoring infrastructure policy reforms and rural poverty reduction in Ghana: The case of Keta Sea Defence Project. Mediterranean Journal of Social Sciences, 5(3), 633. https:// doi.org/10.5901/mjss.2014.v5n3p633.

Jonah, F. E., Agbo, N. W., Agbeti, W., Adjei-Boateng, D., \& Shimba, M. J. (2015). The ecological effects of beach sand mining in Ghana using ghost crabs (Ocypode species) as biological indicators. Ocean and Coastal Management, 112, 18-24. https://doi.org/10.1016/j.ocecoaman.2015.05.001.

Kortatsi, B. K., Young, E., \& Mensah-Bonsu, A. (2005). Potential impact of large scale abstraction on the quality of shallow groundwater for irrigation in the Keta Strip, Ghana. West African Journal of Applied Ecology, 8, 1. https://doi.org/10.4314/wajae.v8i1.45780.

Kumapley, N. K. (1989). The geology and geotechnology of the Keta basin with particular reference to coastal protection. In W. J. M. van der Linden, S. A. P. L. Cloetingh, J. P. K. Kaasschieter, W. J. E. van de Graaff, J. Vandenberghe, \& J. A. M. van der Gun (Eds.), Coastal lowlands: Geology and geotechnology (pp. 311-320). Dordrecht, The Netherlands: Springer.

Kumi, E. N. (2017). The electricity situation in Ghana: Challenges and opportunities (CGD Policy Paper). Washington, DC: Center for Global Development. https:/www.cgdev.org/sites/default/files/electricity-situation-ghana-challenges-and-opportunities.pdf. Last accessed 13 November 2018.

Kuupole, D. D., \& Botchway, D.-V. N. Y. M. (2010). Polishing the pearls of ancient wisdom: Exploring the relevance of endogenous African knowledge systems for sustainable development in postcolonial Africa. Faculty of Arts, 
University of Cape Coast and Centre for Indigenous Knowledge and Organizational Development, Cape Coast, Ghana.

Lauria, V., Das, I., Hazra, S., Cazcarro, I., Arto, I., Kay, S., et al. (2018). Importance of fisheries for food security across three climate change vulnerable deltas. Science of the Total Environment, 640-641, 1566-1577. https:// doi.org/10.1016/j.scitotenv.2018.06.011.

Lavoipierre, G. J. (1973). Development in economics and health. Schistosomiasis epidemic of Lake Volta. Revue de l'infirmière, 23(1), 51-53.

Ly, C. K. (1980). The role of the Akosombo Dam on the Volta river in causing coastal erosion in central and eastern Ghana (West Africa). Marine Geology, 37(3), 323-332. https://doi.org/10.1016/0025-3227(80)90108-5.

Manson, A. A. B., Appeaning Addo, K., \& Mensah, A. (2013). Impacts of shoreline morphological change and sea level rise on mangroves: The case of the Keta coastal zone. E3 Journal of Environmental Research and Management, 40(10), 0334-0343.

Mensah, J. V. (2002). Causes and effects of coastal sand mining in Ghana. Singapore Journal of Tropical Geography, 18(1), 69-88. https://doi. org/10.1111/1467-9493.00005.

MFA. (2011). National irrigation policy, strategies and measures. Accra, Ghana: Ministry of Food and Agriculture (MFA), Government of Ghana. http:// extwprlegs1.fao.org/docs/pdf/gha149500.pdf. Last accessed 13 November 2018. MWWH. (2007). National water policy. Accra, Ghana: Ministry of Water, Works \& Housing (MWWH), Government of Ghana. http://www.gwcl. com.gh/national_water_policy.pdf. Last accessed 13 November 2018.

MWWH. (2011). Riparian buffer zone policy for managing freshwater resources in Ghana. Accra, Ghana: Ministry of Water, Works \& Housing (MWWH), Government of Ghana. http://extwprlegs1.fao.org/docs/pdf/gha149365. pdf. Last accessed 13 November 2018.

Nairn, R. B., \& Dibajnia, M. (2004). Design and construction of a large headland system, Keta Sea Defence Project, West Africa. Journal of Coastal Research, 33, 294-314. Special Issue.

Nairn, R. B., MacIntosh, K. J., Hayes, M. O., Nai, G., Anthonio, S. L., \& Valley, W. S. (1999). Coastal erosion at Keta Lagoon, Ghana: Large scale solution to a large scale problem. Proceedings of the 26th Conference on Coastal Engineering 1998, June 22-26, Copenhagen, Denmark. American society of Civil Engineers. https://doi.org/10.1061/9780784404119.242.

Oguntunde, P. G., Friesen, J., van de Giesen, N., \& Savenije, H. H. G. (2006). Hydroclimatology of the Volta River Basin in West Africa: Trends 
and variability from 1901 to 2002. Physics and Chemistry of the Earth, Parts $A / B / C, 31(18), 1180-1188$. https://doi.org/10.1016/j.pce.2006.02.062.

Opoku-Agyemang, M. (2001a, June 27-July 1). Shifting paradigms: Towards the integration of customary practices into the environmental law and policy in Ghana. Proceedings of 'Securing the future: International Conference on Mining and the Environment', Skellefteå, Sweden. The Swedish Mining Association.

Opoku-Agyemang, M. (2001b, June 27-July 1). Water Resources Commission Act and the nationalisation of water rights in Ghana. Proceedings of 'Securing the future: International Conference on Mining and the Environment', Skellefteå, Sweden. The Swedish Mining Association.

Oteng-Ababio, M., Owusu, K., \& Appeaning Addo, K. (2011). The vulnerabilities of the Ghana coast: The case of Faana-Bortianor. JAMBA: Journal of Disaster Risk Studies, 3(2), 429-442. https://doi.org/10.4102/jamba.v3i2.40.

Paperna, I. (1970). Study of an outbreak of schistosomiasis in the newly formed Volta lake in Ghana. Zeitschrift fur Tropenmedizin und Parasitologie, 21(4), 411-425.

Sarpong, G. A. (2004). Going down the drain? Customary water law and legislative onslaught in Ghana. Paper commissioned by Food and Agriculture Organisation as part of its studies on effect of legislation on Customary Water Rights. Rome, Italy: Food and Agriculture Organisation of the United Nations. Setordzi, I., \& Nyavor, G. (2015). Oil exploration to start soon in Keta in spite of challenges. Joyonline news. http://www.myjoyonline.com/ news/2015/february-5th/oil-exploration-to-startsoon-in-keta-despite-challenges.php. Last accessed 14 November 2016.

Tsidzi, K. E. N., \& Kumapley, N. K. (2001). Coastal erosion in Ghana: Causes and mitigation strategies. In P. G. Marinos, G. C. Koukis, G. C. Tsiambaos, \& G. C. Stournaras (Eds.), Engineering geology and the environment, volume 5 (pp. 3941-3946). Lisse, The Netherlands: A A Balkema.

Tsikata, D. (2006). Living in the shadow of the large dams: Long term responses of downstream and lakeside communities of Ghana's Volta river Project. African Social Studies Series. Leiden, The Netherlands: Brill.

van der Linden, W. J. M., Cloetingh, S. A. P. L., Kaasschieter, J. P. K., Vandenberghe, J., van de Graaff, W. J. E., \& van der Gun, J. A. M. (Eds.). (2013). Coastal lowlands: Geology and geotechnology. Dordrecht, The Netherlands: Springer.

Wiafe, G., Boateng, I., Appeaning Addo, K., Quashigah, P. N. J., Ababio, S. D., \& Laryea, S. (2013). Handbook of coastal processes and management in Ghana. Gloucester, UK: The Choir Press. 
Open Access This chapter is licensed under the terms of the Creative Commons Attribution 4.0 International License (http://creativecommons. org/licenses/by/4.0/), which permits use, sharing, adaptation, distribution and reproduction in any medium or format, as long as you give appropriate credit to the original author(s) and the source, provide a link to the Creative Commons license and indicate if changes were made.

The images or other third party material in this chapter are included in the chapter's Creative Commons license, unless indicated otherwise in a credit line to the material. If material is not included in the chapter's Creative Commons license and your intended use is not permitted by statutory regulation or exceeds the permitted use, you will need to obtain permission directly from the copyright holder. 